\title{
The Effectivenes of Simulation Methods to Improve Communicatio Skill in Clinical Nursing Practice: A Systematic Review
}

\author{
Erfan Rofiqi $^{1}$, Mira Triharini ${ }^{1 *}$, Abdul Aziz Alimul Hidayat ${ }^{2}$ \\ ${ }^{I}$ Faculty of Nursing, Universitas Airlangga, Indonesia \\ ${ }^{2}$ Universitas Muhammadiyah Surabaya, Indonesia \\ * mira-t@fkp.unair.ac.id
}

\begin{abstract}
Communication is one of the competence areas that is needed by nursing students, especially in clinical nursing practice. The purpose of this study was to analyze the effect of the simulation method on improving communication skills in nursing clinical practice. Using Systematic design review. Search for articles was conducted from 29 Apri to 16 Juni 2020 by accessing five electronic databases (Scopus, Science Direct, Pubmed, Ebscohost dan ProQuest). The article year is limited from 2015-2020. Keywords: "Simulation" OR "Roleplay", "communication" AND "Communication Skills" OR "Communication Ability" OR "Communication Competence" and "Nurse" AND "Students". Assessing the quality of articles using the Joanna Briggs Institute Critical Apprational Tool and PRISMA checklist as a guide in article screening. A total of 25 articles were analyzed according to inclusion criteria. The selected article is divided into two broad themes about simulation methods: simulation methods with exercises $(\mathrm{n}=14)$ and simulation methods with roleplay or role-playing $(\mathrm{n}=11)$. The research design uses mostly observational studies (cross-sectional and qualitative studies), Quasi-Experimental, and Randomized Control Trials. The sample was nursing students with a varied sample size ranging from 36 to 160 respondents. Simulation methods with exercises and roleplay or role-playing effective in improving communication skills in nursing clinical practice.
\end{abstract}

Keywords: Simulation method, Communication skill, Nursing Practice 


\section{STRADA Jurnal Ilmiah Kesehatan}

DOI: $10.30994 /$ sjik.v9i2.420

ISSN: 2252-3847 (print); 2614-350X (online)

Vol.9 No.2 November 2020 Page.1238-1249

\section{BACKGROUND}

Communication skills are very important for a nursing student (Stevens, Mcniesh, \& Goyal, 2019). Beginning nursing students have knowledge, experience, and few opportunities to practice communication which can negatively impact communication skills (Yu, 2017) as well as their learning abilities in clinical practice (White, 2015). Existing research states that there are several interventions that can be used to improve student communication skills. The method applied during education to improve a student's communication skills is one of them is the simulation method, but the simulation method applied still cannot guarantee that it can have a significant effect on student communication skills. (Blake \& Blake, 2019). Based on research conducted in Turkey, it was stated that as many as $76 \%$ of the 249 students who practice nursing clinics experience communication problems and most of these $66 \%$ of communication problems occur between students and patients. (Öztürk, 2015). Communication is closely related to the health care process and is included in the target patient safety standards. According to James (2016), there are as many as 440,000 people die each year due to mistakes which are accidental or unwanted injuries. $80 \%$ of these accidental incidents are serious medical errors that occur due to poor communication between nursing service providers and patients (Blake \& Blake, 2019). According to WHO (2016), one of the causes related to medication errors is poor communication which has an impact on patient safety in the hospital. Communication is influenced by several factors, namely perception, values, emotions, background, roles, knowledge and relationships (Amirah, 2016). The knowledge factor is very closely related to the learning process received by students during education and what determines the success of this learning depends on the learning method used (Alamrani, Alammar, Alqahtani, \& Salem, 2017). The learning method that can be done is the simulation method. The simulation method as a step in learning can effectively increase knowledge and skills because students can immediately see what is being learned applied not only in theory. Several studies have been carried out related to learning methods that can improve the communication skills of nursing students. Based on the results of research submitted by Basak, Demirtas and Iyigun (2019), it was stated that the learning method with simulation has a positive effect on the communication skills of nursing students.

\section{METHODS}

This systematic review was conducted to provide a comprehensive systematic description of the simulation method to improve the communication skills and selfconfidence of nursing students. The protocol in this systematic review refers to The Center for Review and Dissemination and the Joanna Briggs Institute Guideline as a guide in assessing the quality of the study. Systematic reviews will be evaluated using the PRISMA checklist to determine the selection of studies that have been identified. This systematic review will be registered at Airlangga University, Surabaya. Literature search strategy using 5 databases; Scopus, Science direct, Pubmed, Ebscohost, and ProQuest. The search was carried out from 29 April 2020 to 16 June 2020 to identify relevant research. Phrase searching used is the boolean logic used is "And", and "Or". In addition, the search process for articles is limited to article journals and in English and the year limitation focuses on articles published in the last 5 years. Keywords in this Systematic review are adjusted to Medical Subject Heading (MeSH) Pubmed Communication, simulation and nursing student. 


\section{STRADA Jurnal Ilmiah Kesehatan}

DOI: $10.30994 /$ sjik.v9i2.420

ISSN: 2252-3847 (print); 2614-350X (online)

Vol.9 No.2 November 2020 Page.1238-1249

\section{RESULTS}

The results of the article analysis found that 4 studies were Randomized Control Trials, 14 studies used Quasy-Experimental, 3 cross-sectional studies and 3 qualitative studies. Based on these results, after the critical appraisal was carried out using the JBI critical appraisal tools, a quality score was given.

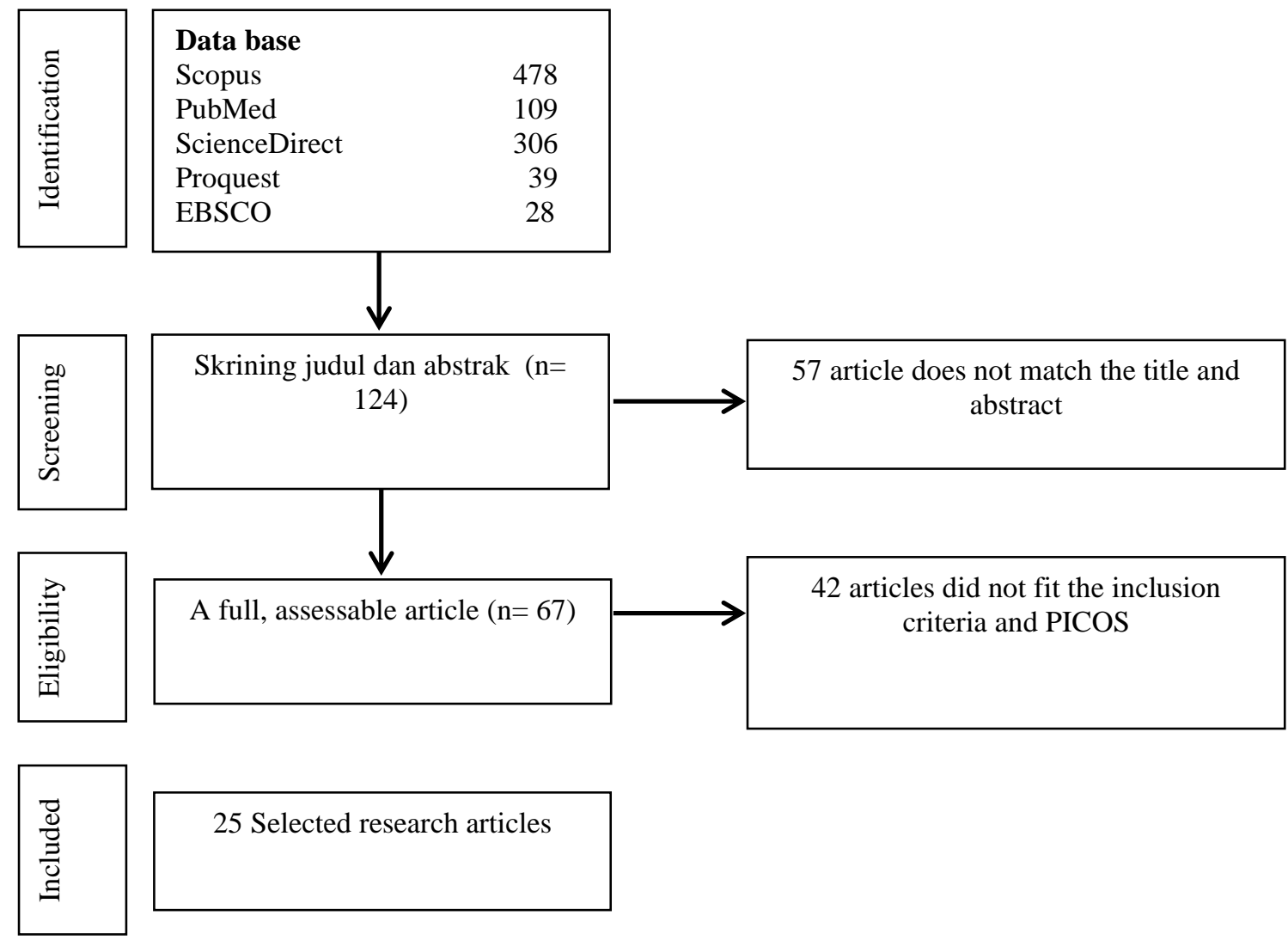

Figure 1. Study selection flow diagram

The studies included in this systematic review article consisted of 10 studies in the USA carried out in laboratories, classrooms, nursery departments, hospitals and simulation wards, 4 studies in Korea were conducted in laboratories, simulation education centers and clinical learning centers, 2 studies were conducted in Norway, Australia and China were conducted in laboratories, classrooms, and hospitals, and 1 other study was conducted in Turkey, Ireland, Taiwan, England, and Sweden conducted in classrooms and online. The time of the research was conducted between 2015 - 2019. The simulation method is based on the results of the study conducted, it was found that there were 2 types of simulation methods to improve communication skills in nursing. First, the type of simulation method in the form of both offline and online exercises. There are 18 studies, namely patient standard-based, debriefing simulation, environment-based, teach-back simulation, video simulation and online simulation. Second, the type of simulation method using roleplay or role playing, there are 7 studies consisting of drama, psychodrama, roleplay and scenarios. Respondents in this study were nursing students from various countries who were not limited by education levels. This study has mentioned a simulation method for communication skills in nursing practice, with a total of 2,060 participants. Respondents / participants for research with quasy experimental ranging from 35-160 people, RCTs 


\section{STRADA Jurnal Ilmiah Kesehatan}

DOI: $10.30994 /$ sjik.v9i2.420

ISSN: 2252-3847 (print); 2614-350X (online)

research 109-132 people, cross sectional 82-150 people, and qualitative research 12-141 people. The results can be seen in table 1 .

Table 1. Summary of Literature Search Results for Systematic Reviews

\begin{tabular}{|c|c|c|}
\hline No & $\begin{array}{c}\text { Author, year and } \\
\text { country }\end{array}$ & Study design \\
\hline 1 & $\begin{array}{l}\text { Ok, Kutlu and } \\
\text { Ates, } \\
\text { Turkey }\end{array}$ & $\begin{array}{l}\text { Design: Quasy-experimental } \\
\text { Sample: } 85 \text { nursing students from } 2 \\
\text { different universities } \\
\text { Variables: Standard-based simulation } \\
\text { of patients and communication skills } \\
\text { Instruments: personal information } \\
\text { questionnaire, communicational skills } \\
\text { inventory, and state-trait anxiety } \\
\text { inventory. } \\
\text { Analysis: independent sample t test }\end{array}$ \\
\hline 2 & $\begin{array}{l}\text { Beaird, Nye and } \\
\text { Ii, (2017) USA }\end{array}$ & $\begin{array}{l}\text { Design: Quasy-experimental } \\
\text { Sample: } 112 \text { nursing students } \\
\text { Variable: Simulation using reflective } \\
\text { video and communication skills } \\
\text { Instrument: The Macy } \\
\text { Communication Scale is based on the } \\
\text { NYU model from the Macy Initiative } \\
\text { in Health Communications Analysis: } \\
\text { independent sample t test }\end{array}$ \\
\hline
\end{tabular}

3 Blake and Blake, Design: Quasy-experimental

(2019) USA Sample: 35 nursing students from nursing programs located in westcentral United States Variables: Standard-based simulation of patients and Communication skills

Instruments: a pretest and an identical Posttest self-efficacy and therapeutic communication questionnaire

Analysis: independent sample t test

4 Breen et al., Design: Randomized Control Trial (2019) Ireland with three parallel arms

Sample: 109 people in the third year of nursing school and 201 medical students in the last year

Variables: E-learning and Proficiency-based progression (PBP) simulation and communication skills Instruments: ISBAR Tools

Analysis: The

Kruskal-Wallis test
Summary of results

The comparison of the scores obtained with

the intervention group before and after being given the patient standard-based simulation intervention showed a statistically significant improvement in the communication skills of the intervention group after the simulation exercise with a score $(p<0.001)$.

The results obtained were that the simulation using reflective video affected changes in the communication ability score ( $\mathrm{P}$ 0.1874), although there was no significant difference between the two groups, the intervention group did have a higher score than the control group for the second, third, and fourth simulations. For simulation intervention using the Patient Standard (SP) showed a significant relationship was found between student selfassessment and SP ratings ( $\mathrm{p}<.0001)$.

From the results of the Wilcoxon test, there was an increase in student self-efficacy in communication skills after being given a simulation with patient standards indicated by five questions, all of which were significant with $\mathrm{p}<0.01$.

The simulation results show that the addition of a simulation program Proficiency-based progression (PBP) to the e-learning module can provide superior skills for ISBAR communication in terms of worsening patient relationships than the e-learning module either alone or in combination with standard simulations with significant results, meaning 8.5 (1.7), rather than either the E-learning group, means 5.8 (1.6), $\mathrm{p}<0.000$, or the standard E-learning + Simulation group, mean 6.3 (2.1), p <0.000. Similarly, the combined errors and critical errors were significantly less in the E-learning + Proficiency-based progression (PBP) group, meaning 3.7 (1.6), compared to the Group E group, mean 5.9 (2.1), $\mathrm{p}<0.000$, or group $\mathrm{E}+\mathrm{S}$, mean 5.2 (1.5), $\mathrm{p}<0.01$. 


\section{STRADA Jurnal Ilmiah Kesehatan}

DOI: $10.30994 /$ sjik.v9i2.420

ISSN: 2252-3847 (print); 2614-350X (online)

Vol.9 No.2 November 2020 Page.1238-1249

\begin{tabular}{|c|c|c|c|}
\hline No & $\begin{array}{l}\text { Author, year and } \\
\text { country }\end{array}$ & Study design & Summary of results \\
\hline 5 & $\begin{array}{lr}\text { Donovan } & \text { and } \\
\text { Msn, } & \text { (2019) } \\
\text { USA } & \end{array}$ & $\begin{array}{l}\text { Design: Pre-Post survey intervention } \\
\text { Sample: } 160 \text { undergraduate nursing } \\
\text { students. Variable: Simulation with } \\
\text { video and communication skills } \\
\text { Instruments: A self-reported pre and } \\
\text { post simulation survey } \\
\text { Analysis: one-sample sample } \\
\text { t-tests. }\end{array}$ & $\begin{array}{l}\text { There was a significant increase in the level of } \\
\text { self-confidence and the ability of students to } \\
\text { communicate well with patients between } \\
\text { before and after intervention }(\mathrm{p}<0.001) \text {. }\end{array}$ \\
\hline 6 & $\begin{array}{l}\text { Gaylle, (2019) } \\
\text { USA }\end{array}$ & $\begin{array}{l}\text { Design: Quasi-experimental, mixed- } \\
\text { method design } \\
\text { Sample: } 67 \text { senior nursing students } \\
\text { enrolled in a clinical rotation of } \\
\text { psychiatry in the community } \\
\text { Variables: Debriefing simulation and } \\
\text { communication skills } \\
\text { Instrument: psychiatric assessment } \\
\text { and therapeutic communication } \\
\text { Analysis: independent and paired } \\
\text { sample t tests }\end{array}$ & $\begin{array}{l}\text { There was a greater improvement in } \\
\text { therapeutic communication in the simulated } \\
\text { treatment group. The difference in means } \\
\text { between the simulation and postsimulation } \\
\text { groups for therapeutic communication (mean, } \\
1.39 \text { and } 0.83 \text { ) was statistically and practically } \\
\text { significant from pre-test to post-test, with a } \\
\text { very large effect size of } 0.98 \text {. }\end{array}$ \\
\hline 7 & $\begin{array}{l}\text { Haugland and } \\
\text { Reime, (2018) } \\
\text { Norwegia }\end{array}$ & $\begin{array}{l}\text { Design: Qualitative } \\
\text { Sample: } 12 \text { first year undergraduate } \\
\text { nursing students } \\
\text { Variable: simulation with scenario } \\
\text { and communication skills } \\
\text { Instrument: Open-ended question } \\
\text { verbatim } \\
\text { Analysis: Focus group }\end{array}$ & $\begin{array}{l}\text { Scenario-based simulation training becomes a } \\
\text { valuable didactic method in order to improve } \\
\text { nursing students' communication skills, } \\
\text { increase ethical reflection and the ability to } \\
\text { avoid the use of coercion in demanding } \\
\text { situations in dementia care. This method can } \\
\text { prepare nursing students for clinical practice. }\end{array}$ \\
\hline 8 & $\begin{array}{l}\text { Karlsen, Kristin } \\
\text { and Lise, (2017) } \\
\text { Norwegia }\end{array}$ & $\begin{array}{l}\text { Design: Qualitative Study, } \\
\text { exploratory and descriptive design. } \\
\text { Sample: } 14 \text { respondents of } \\
\text { postgraduate students in intensive } \\
\text { care. } \\
\text { Variables: } \\
\text { simulation and communication skills } \\
\text { Instrument: Open-ended question } \\
\text { verbatim } \\
\text { Analysis: Thematic analysis }\end{array}$ & $\begin{array}{l}\text { The main finding of this study was that } \\
\text { students reported improved communication } \\
\text { skills after taking a communication course } \\
\text { with an environmentally based simulation. } \\
\text { The analysis resulted in three main themes: } \\
\text { "awareness", "ice-breaking" and "challenging } \\
\text { learning environment." }\end{array}$ \\
\hline 9 & $\begin{array}{l}\text { Kim and Cho, } \\
\text { (2018) Korea }\end{array}$ & $\begin{array}{l}\text { Design: Cross Sectional } \\
\text { Sample: } 82 \text { senior nursing students } \\
\text { Variable: simulation method with } \\
\text { problem based learning (PBL) and } \\
\text { communication skills } \\
\text { Instrument: communication } \\
\text { apprehension questionaire } \\
\text { Analysis: paired-samples t test }\end{array}$ & $\begin{array}{l}\text { The results showed that SIM-PBL is a } \\
\text { teaching-learning strategy that reduces } \\
\text { communication worries and increases the } \\
\text { clinical self-efficacy of nursing students in } \\
\text { communicating. }\end{array}$ \\
\hline 10 & $\begin{array}{l}\text { Lai, } \\
\text { Taiwan }\end{array}$ & $\begin{array}{l}\text { Design: Pre-Experimental } \\
\text { Sample: } 50 \text { nursing students } \\
\text { Variable: Simulation with online } \\
\text { video and communication skills } \\
\text { Instrument: Interpersonal } \\
\text { Communication Assessment Scale } \\
\text { (ICAS) } \\
\text { Analysis: paired-samples t test }\end{array}$ & $\begin{array}{l}\text { There was a significant result of the } \\
\text { intervention given to improving students' } \\
\text { communication skills }(\mathrm{p}<0.001) \text {. }\end{array}$ \\
\hline 11 & $\begin{array}{l}\text { Maclean et al., } \\
\text { (2019) Australia }\end{array}$ & $\begin{array}{l}\text { Design: Qualitative } \\
\text { Sample: } 141 \text { undergraduate nursing }\end{array}$ & $\begin{array}{l}\text { Using simulated patient and video-assisted } \\
\text { reflection when teaching communication skills }\end{array}$ \\
\hline
\end{tabular}




\section{STRADA Jurnal Ilmiah Kesehatan}

DOI: $10.30994 /$ sjik.v9i2.420

ISSN: 2252-3847 (print); 2614-350X (online)

Vol.9 No.2 November 2020 Page.1238-1249

\begin{tabular}{|c|c|c|c|}
\hline No & $\begin{array}{c}\text { Author, year and } \\
\text { country }\end{array}$ & Study design & Summary of results \\
\hline & & $\begin{array}{l}\text { students } \\
\text { Variables: Simulation with reflective } \\
\text { video and communication skills } \\
\text { Instrument: Interviews } \\
\text { Analysis: Thematic analysis }\end{array}$ & $\begin{array}{l}\text { shows that the process helps to gain a greater } \\
\text { understanding of communication skills in } \\
\text { patient discharge. }\end{array}$ \\
\hline 12 & $\begin{array}{l}\text { Maclean et al., } \\
\text { (2018) Australia }\end{array}$ & $\begin{array}{l}\text { Design: A quasi-experimental control } \\
\text { group } \\
\text { Sample: } 50 \text { second or third year } \\
\text { undergraduate students } \\
\text { Variables: Tech-Back simulation and } \\
\text { communication skills } \\
\text { Instrument: Two subscales of the } \\
\text { Quality Discharge Teaching Scale } \\
\text { (QDTS) } \\
\text { Analysis: Independent group } \\
\text { multivariate analysis of variance } \\
\text { (MANOVA) }\end{array}$ & $\begin{array}{l}\text { Significant improvement in students' } \\
\text { communication skills in patient discharge was } \\
\text { achieved in the interaction and information } \\
\text { group compared to the control group with a } \mathrm{P} \\
\text { value }<0.001\end{array}$ \\
\hline 13 & $\begin{array}{l}\text { Martin and } \\
\text { Chanda, (2016) } \\
\text { USA }\end{array}$ & $\begin{array}{l}\text { Design: A quasi-experimental, one } \\
\text { group, preepost test } \\
\text { Sample: } 28 \text { pre-licensed nursing } \\
\text { students } \\
\text { Variable: Standard-based simulation } \\
\text { of patient and communication skills } \\
\text { Instruments: Previous Knowledge } \\
\text { and Demographic } \\
\text { Questionnaire, Confidence With } \\
\text { Communication Skills Scale, } \\
\text { Therapeutic Communication Pretest } \\
\text { and Posttest } \\
\text { Analysis: Dependent t tests }\end{array}$ & $\begin{array}{l}\text { There was a significant increase }(\mathrm{p}<0.000) \text { in } \\
\text { students' reported self-confidence with } \\
\text { communication skills and knowledge after } \\
\text { mental health simulation experiences using } \\
\text { patient standards. }\end{array}$ \\
\hline 14 & $\begin{array}{lr}\text { Neilson } & \text { and } \\
\text { Reeves, } & (2019) \\
\text { UK }\end{array}$ & $\begin{array}{l}\text { Design: Cross Sectonal } \\
\text { Sample: } 158 \text { nursing students. } \\
\text { Variable: Simulation based on drama } \\
\text { and communication skills } \\
\text { Instrument: A simple communication } \\
\text { checklist } \\
\text { Analysis: Dependent t tests }\end{array}$ & $\begin{array}{l}\text { Results indicated that exercise had a positive } \\
\text { impact on participants' perceptions of ability } \\
\text { to communicate clearly in end-of-life care } \\
\text { settings. The results also augment the } \\
\text { literature by demonstrating the use of novel, } \\
\text { and the effectiveness of, forum theater in } \\
\text { describing the translation of communication } \\
\text { theory into practice, in the context of late life } \\
\text { pediatric care. The identified impacts of the } \\
\text { various teaching methods used and the } \\
\text { collaborative interdisciplinary approach will } \\
\text { be discussed and the learning process } \\
\text { explored. }\end{array}$ \\
\hline 15 & $\begin{array}{l}\text { Kellie Long, } \\
\text { (2018) USA }\end{array}$ & $\begin{array}{l}\text { Design: Quasy experimental one- } \\
\text { group pretest / posttest design } \\
\text { Sample: } 33 \text { undergraduate nursing } \\
\text { students. Variable: patient standard- } \\
\text { based simulation and communication } \\
\text { skills } \\
\text { Instruments: Use of NLN Surveys } \\
\text { and Research Instruments } \\
\text { Analysis: A paired sample dependent } \\
\text { t-test }\end{array}$ & $\begin{array}{l}\text { The results showed that the nursing students } \\
\text { had higher self-efficacy scores helping them } \\
\text { identify ways to improve communication, and } \\
\text { would help them communicate with patients } \\
\text { in a clinical setting statistically with a } \\
\text { significance of } p=0.001 . .\end{array}$ \\
\hline 16 & $\begin{array}{l}\mathrm{Li}, \quad \mathrm{Li}, \quad \mathrm{Gu}, \\
\text { Zhang, }\end{array}$ & $\begin{array}{l}\text { Design: Randomized controlled trial } \\
\text { Sample: } \quad 132 \quad \text { nursing students }\end{array}$ & $\begin{array}{l}\text { The results obtained were communication } \\
\text { skills, empathy, and self-efficacy in the }\end{array}$ \\
\hline
\end{tabular}




\section{STRADA Jurnal Ilmiah Kesehatan}

DOI: $10.30994 /$ sjik.v9i2.420

ISSN: 2252-3847 (print); 2614-350X (online)

Vol.9 No.2 November 2020 Page.1238-1249

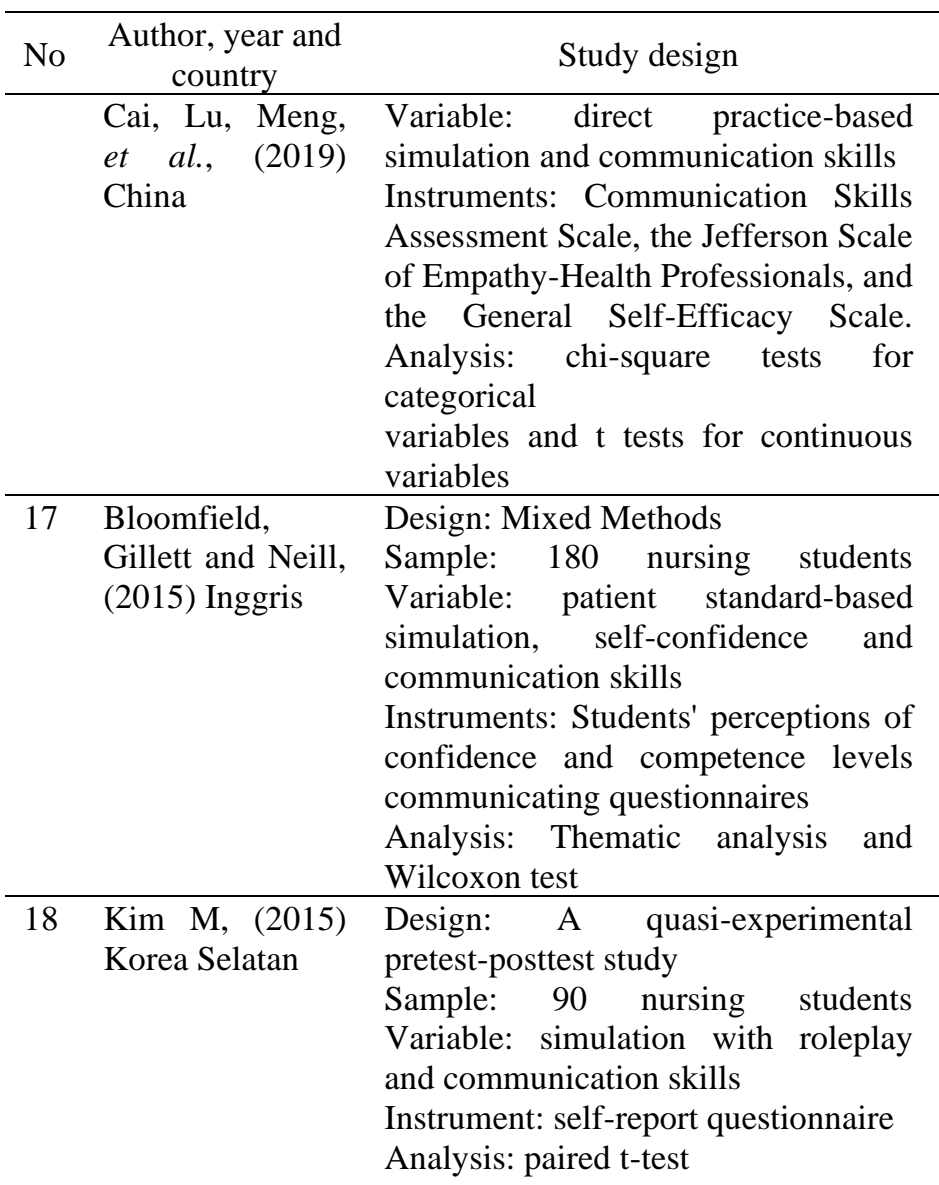

19 Beauvais, Özbaş Design: A quasi-experimental and Wheeler, pretest-posttest study

(2019) USA Sample: 84 nursing students Variable: simulation with psychodrama and communication skills Instruments: process recordings and Frommelt Attitude Toward Care of the Dying (FATCOD) Scale Analysis: paired t-test analysis

20 Stevens, Design: Pre-post test intervention Mcniesh and study

Goyal, (2019) Sample: 35 nursing students USA Variable: simulation with selfconfidence workshop and communication skills Instruments: Nursing Anxiety and Self-Confidence With Clinical Decision-Making Scale Analysis: paired t-test analysis Simulation was found to be an effective way to prepare students to communicate with dying patients and their families with a significant increase $(p=0.5)$ in competence and self-confidence. The themes of the FGD were responding to sadness and anger, difficulty dealing with emotions, knowing the "right things" to say, and lack of experience..

The results showed that the Patient Role Simulation Practicum was effective in improving problem-solving abilities and communication skills, although not significant. The problem-solving ability level of the experimental group was significantly higher than the control group $(\mathrm{t}=2.30, \mathrm{p}=$ .024).

The study highlighted the value of psychodrama as a strategy that can improve the communication skills of nursing students. Statistically significant difference in attitude improvement between the group receiving the psychodrama intervention and the control group $(t=27.19, \mathrm{p}=.000)$.

Mean statistically significant improvement in self-confidence from pre- (range $=70$ to 140 ) to post intervention (range $=75$ to 157 ), $\mathrm{p}=<$. $05, t=-2,434$. The findings support the use of SBAR and continuous simulation as an organizing tool for increasing nursing student confidence during communication; However, further effort is needed to qualitatively examine how these tools are driving these changes.

21 Jeong and Kim, Design: Randomized control pre-post (2020) Korea test study

Sample: 54 nursing students Variable: simulation based on patient standards and communication skills Instruments: Fall-related patient safety competence and communication clarity The SBAR group showed improved related skills and communication clarity compared to the handoff group. There was a significant difference in knowledge before and after intervention $\quad(\mathrm{P} \quad<0.001$. SBAR-based simulation programs can be used as an educational intervention for nursing students not only to improve skills in reporting and 


\section{STRADA Jurnal Ilmiah Kesehatan}

DOI: $10.30994 /$ sjik.v9i2.420

ISSN: 2252-3847 (print); 2614-350X (online)

Vol.9 No.2 November 2020 Page.1238-1249

\begin{tabular}{|c|c|c|c|}
\hline No & $\begin{array}{l}\text { Author, year and } \\
\text { country }\end{array}$ & Study design & Summary of results \\
\hline & & Analysis: Anova & $\begin{array}{l}\text { communication but to prevent or handle } \\
\text { patient safety accidents efficiently. }\end{array}$ \\
\hline 22 & $\begin{array}{l}\text { Wang et al., } \\
(2015) \text { Cina }\end{array}$ & $\begin{array}{l}\text { Design: Quasy-Experimental } \\
\text { Sample: } 19 \text { nursing students } \\
\text { Variable: video simulation and } \\
\text { communication skills Instrument: } \\
\text { pre- / post-workshop questionnaire } \\
\text { SBAR tools } \\
\text { Analysis: A Wilcoxon } \\
\text { signed-rank test }\end{array}$ & $\begin{array}{l}\text { The SBAR workshop in combination with } \\
\text { video-stimulated recall and roleplay case } \\
\text { scenarios significantly improved the } \\
\text { knowledge and communication skills of } \\
\text { Chinese nursing students with SBAR. The } \\
\text { total score increased significantly from } 40.9 \pm \\
5.0 \text { to } 49.2 \pm 5.9(\mathrm{p}<0.01) \text {. In addition, } 93.8 \% \\
\text { of students agreed and strongly agreed that } \\
\text { they would use SBAR during clinical practice. }\end{array}$ \\
\hline 23 & $\begin{array}{lll}\text { Yeh et } & a l ., \\
\text { (2019) USA } & \end{array}$ & $\begin{array}{l}\text { Design: Quasy-Experimental } \\
\text { Sample: } 81 \text { nursing students } \\
\text { Variables: online simulation and } \\
\text { communication skills Instruments: } \\
\text { story-specific checklists } \\
\text { adapted from the identification, } \\
\text { situation, background, } \\
\text { assessment, recommendation } \\
\text { (ISBAR) Interprofessional } \\
\text { Communication Rubric (IICR) } \\
\text { Analysis: ANCOVA }\end{array}$ & $\begin{array}{l}\text { The results showed that there was a significant } \\
\text { change in students' communication skills after } \\
\text { being given a course with online simulation }\end{array}$ \\
\hline 24 & $\begin{array}{lr}\text { Webster } & \text { and } \\
\text { Carlson, } & (2019) \\
\text { Swedia } & \end{array}$ & $\begin{array}{l}\text { Design: Cross Sectional } \\
\text { Sample: } 114 \text { nursing students } \\
\text { Variable: patient standard-based } \\
\text { simulation and communication skills. } \\
\text { Instrument: behavior element scale } \\
\text { Analysis: chi-square anlysis }\end{array}$ & $\begin{array}{l}\text { Standardized patient simulations are needed to } \\
\text { motivate nursing students to build therapeutic } \\
\text { relationship skills with seriously ill people to } \\
\text { improve person-centered care. }\end{array}$ \\
\hline 25 & $\begin{array}{l}\text { Choia et al., } \\
\text { (2020) Korea }\end{array}$ & $\begin{array}{l}\text { Design: Randomized control trials } \\
\text { Sample: } 135 \text { nursing students } \\
\text { Variable: simulation with video and } \\
\text { communication skills Instrument: } \\
\text { Questionnaires } \\
\text { consisted of scales on communication } \\
\text { knowledge, learning self-efficacy, } \\
\text { communication efficacy, and } \\
\text { satisfaction } \\
\text { Analysis: a t-test and chi-square test }\end{array}$ & $\begin{array}{l}\text { There was a significant change in students' } \\
\text { knowledge and communication skills after } \\
\text { being given intervention with the ComEd } \\
\text { program which contained video simulations (P } \\
<0.001) \text {. }\end{array}$ \\
\hline
\end{tabular}

\section{DISCUSSION}

Based on the results of the systematic review, there are 2 types of simulation methods, namely the simulation method in the form of training and the simulation method in the form of roleplay or role playing. The discussion in this systematic review will focus on simulation methods that can and can be done in Indonesia. According to previous research conducted in Indonesia, the simulation method uses both offline and online training methods (Indriasari, 2016) and roleplay simulation (Sukamto \& Putri, 2019) effective in increasing student knowledge and skills. There are various types of simulation methods, one of which is in the form of training. Simulation methods in the form of exercises both offline and online as an intervention in improving communication skills in nursing practice. Some of them that can be applied are patient standard-based simulation methods (Martin and Chanda, 2016; Ok, Kutlu and Ates, 2019; Kellie Long, 2018; Blake and Blake, 2019), simulation with video (Beaird et al., 2017; Donovan \& Msn, 2019; 


\section{STRADA Jurnal Ilmiah Kesehatan}

DOI: $10.30994 /$ sjik.v9i2.420

ISSN: 2252-3847 (print); 2614-350X (online)

Vol.9 No.2 November 2020 Page.1238-1249

Maclean et al., 2019) and online simulation (Yeh et al., 2019). The second simulation is roleplay or role playing (Wang et al., 2015; Wang et al., 2015).

Standardized Patient, namely people who are trained to act as real patients to provide specific responses to certain medical conditions (Gaylle, 2019). Martin and Chanda, (2016) define standard patients as people who are trained to represent the characteristics of a patient. The patient standard allows students to be immediately exposed to feedback on the success or lack of success of being used communication strategies. In other words, students will immediately know whether their approach is working or not because of how the patient is responding. The effectiveness of simulations using standard patients has been reported in terms of increased self-confidence, improved communication skills, satisfaction with learning experiences, overall decreased anxiety of individuals with mental illness, and increased self-reflection and availability of immediate feedback. (Martin \& Chanda, 2016). Video-assisted debriefing / reflection (VAD) is used because it may be difficult for participants to remember precisely the events in the simulation. Watching a video performance provides an opportunity for performance evaluation without relying on participants' own memory or interpretation of the simulation session (Cheng et al., 2016). Usually, the questions and answers, under the guidance of the facilitator, are resolved as a group. Chronister and Brown, (2012) retention of knowledge, skills, and response time measured by students completing simulated cardiopulmonary resuscitation using video assistance and verbal debriefing methods. They found that using video and verbal debriefing together positively influenced nursing skills and response time. Online or virtual simulation as a strategy for the future direction of interprofessional communication training (Foronda, Macwilliams, \& Mcarthur, 2016). Asynchronous online simulation, which provides experiential learning opportunities without the limitations of facility scheduling and faculty time, presents such an educational modality (Lai, 2016). Using clinical stories and asking students to verbalize their reports helps simulate experiences that are realistic but in a safe environment. Online simulation practice opportunities overcoming structural barriers and scheduling on-site training sessions by offering alternative online educational methodologies that can help preserve resource scarcity (Yeh et al., 2019). The educational intervention includes a series of asynchronous online simulation-based DP sessions designed to provide students with structured and focused practice opportunities. We hypothesized that the intervention would have a positive impact on the ability of nursing students to meet the MPS and their performance and confidence levels in reporting critical incidents of patients.

Roleplay or role-playing is a form of simulation method. Role playing means that students are required to be able to play a role as the simulation plan is drawn up. The simulation method in this form that can be applied in Indonesia is simulation with roleplay. Roleplay helps students learn to work closely with their team members using scripts assigned to them different roles in a multidisciplinary team in a variety of scenarios and provides an imaginary context in which they can investigate the problems and behaviors of participants' different personalities and roles by enhancing perceptions and critical thinking. they are skills (Wang et al., 2015). Active stimulation by roleplay has been used as an educational strategy in the study of educational ethics (Sukamto \& Putri, 2019).

\section{CONCLUSION}

Improving communication skills for students is very important in the nursing practice process. The simulation method is a learning method that can improve communication skills. The simulation method provides a good stimulus because this activity is carried out 


\section{STRADA Jurnal Ilmiah Kesehatan}

DOI: $10.30994 /$ sjik.v9i2.420

ISSN: 2252-3847 (print); 2614-350X (online)

Vol.9 No.2 November 2020 Page.1238-1249

directly by students so that it can influence responses and skill changes. There are two types of simulation methods to improve communication skills, namely simulation methods in the form of offline and online training and simulation methods in the form of roleplay or role playing. The simulation method that can be applied in Indonesia is simulation in the form of training, including based on patient standards, simulation with video and online simulation. Second, the type of simulation method with roleplay or role playing. Both types of simulation methods are effective in improving the communication skills of nursing students.

\section{REFERENCES}

Alamrani, M., Alammar, K., Alqahtani, S., \& Salem, O. A. (2017). Comparing the Effects of Simulation-Based and Traditional Teaching Methods on the Critical Thinking Abilities and Self-Confidence of Nursing Students. 00(0), 1-6.

Amirah. (2016). Hubungan komunikasi (mendengarkan, menjelaskan dan kompetensi) dengan kepercayaan, kepuasan dan loyalitas pasien instalasi rawat jalan rumah sakit di Makassar. FKM Makassar.

Beaird, G., Nye, C., \& Ii, L. R. T. (2017). The Use of Video Recording and Standardized Patient Feedback to Improve Communication Performance in Undergraduate Nursing Students. Clinical Simulation in Nursing, 13(4), 176-185. https://doi.org/10.1016/j.ecns.2016.12.005

Beauvais, A. M., Özbaş, A. A., \& Wheeler, K. (2019). intelligence and self-reflection. 10(3), 103-110. https://doi.org/10.14744/phd.2019.96636

Blake, T., \& Blake, T. (2019). Improving therapeutic communication in nursing through simulation exercise. Teaching and Learning in Nursing, 14(4), 260-264. https://doi.org/10.1016/j.teln.2019.06.003

Bloomfield, J. G., Gillett, K., \& Neill, B. O. (2015). Enhancing student communication during end-of-life care: A pilot study. 1651-1661. https://doi.org/10.1017/S147895151500022X

Breen, D., Brien, S. O., Mccarthy, N., \& Gallagher, A. (2019). Effect of a proficiencybased progression simulation programme on clinical communication for the deteriorating patient: a randomised controlled trial. 1-8. https://doi.org/10.1136/bmjopen-2018-025992

Cheng, A., Eppich, W., Grant, V., Sherbino, J., Zendejas, B., \& Cook, D. A. (2016). medical education in review Debrie fi ng for technology-enhanced simulation: a systematic review and meta-analysis. 657-666. https://doi.org/10.1111/medu.12432

Choia, H., B Leea, U., Jeona, Y. S., \& Kimc, C. (2020). Efficacy of the computer simulation-based, interactive communication education program for nursing students.

Donovan, L. M., \& Msn, L. K. M. (2019). Nurse Education in Practice Expanding nursing simulation programs with a standardized patient protocol on therapeutic communication. Nurse Education in Practice, 38(March), 126-131. https://doi.org/10.1016/j.nepr.2019.05.015

Foronda, C., Macwilliams, B., \& Mcarthur, E. (2016). AC SC. Nurse Education in Practice. https://doi.org/10.1016/j.nepr.2016.04.005

Gaylle, D. (2019). In-simulation Debriefing Increases Therapeutic Communication Skills. 44(6), 295-299. https://doi.org/10.1097/NNE.0000000000000643

Haugland, V. L., \& Reime, M. H. (2018). Scenario-based simulation training as a method to increase nursing students $>$ competence in demanding situations in dementia care. A mixed method study. Nurse Education in Practice. 


\section{STRADA Jurnal Ilmiah Kesehatan}

DOI: $10.30994 /$ sjik.v9i2.420

ISSN: 2252-3847 (print); 2614-350X (online)

Vol.9 No.2 November 2020 Page.1238-1249

https://doi.org/10.1016/j.nepr.2018.08.008

Indriasari, F. N. (2016). Pengaruh Pemberian Metode Simulasi Siaga Bencana Gempa Bumi terhadap Kesiapsiagaan Anak di Yogyakarta. Jurnal Keperawatan Soedirman (The Soedirman Journal of Nursing), 11(3), 1-7.

Jeong, J. H., \& Kim, E. J. (2020). Development and Evaluation of an SBAR-based Fall Simulation Program for Nursing Students. Asian Nursing Research, 14(2), 114-121. https://doi.org/10.1016/j.anr.2020.04.004

Karlsen, M. W., Kristin, A., \& Lise, A. (2017). confirming communication skills : A descriptive qualitative study. Intensive \& Critical Care Nursing. https://doi.org/10.1016/j.iccn.2017.04.005

Kellie Long. (2018). Effectiveness of Standardized Patients on the Self-Efficacy of Nursing Students 'Communication Skills.

Kim M. (2015). Patient role simulation practicum in maternity nursing: The effects on problem solving ability, self- directed learning ability, and communication skill ( Article).

Kim, Y., \& Cho, O. (2018). SIMULATION EDUCATION WITH PROBLEM-BASED LEARNING : EFFECT ON NURSING STUDENTS '. 46(1), 151-160.

Lai, C. (2016). Computers \& Education Training nursing students' communication skills with online video peer assessment. Computers \& Education, 97, 21-30. https://doi.org/10.1016/j.compedu.2016.02.017

Li, J., Li, X., Gu, L., Zhang, R., Zhao, R., Cai, Q., ... Wei, H. (2019). Effects of Simulation-Based Deliberate Practice on Nursing Students 'Communication , Empathy, and Self- Efficacy. 58(12), 2019. https://doi.org/10.3928/0148483420191120-02

Maclean, S., Geddes, F., Kelly, M., \& Della, P. (2019). Video Reflection in Discharge Communication Skills Training With Simulated Patients: A Qualitative Study of Nursing Students' Perceptions. Clinical Simulation in Nursing, 28, 15-24. https://doi.org/10.1016/j.ecns.2018.12.006

Maclean, S., Lecturer, R. N., Kelly, M., Community, A., Geddes, F., Manager, P., \& Della, P. (2018). Evaluating the Use of Teach-Back in Simulation Training to Improve Discharge Communication Practices of Undergraduate Nursing Students. Clinical Simulation in Nursing, 22, 13-21. https://doi.org/10.1016/j.ecns.2018.06.005

Martin, C. T., \& Chanda, N. (2016). Mental Health Clinical Simulation: Therapeutic Communication. Clinical Simulation in Nursing, 12(6), 209-214. https://doi.org/10.1016/j.ecns.2016.02.007

Neilson, S. J., \& Reeves, A. (2019). Nurse Education in Practice The use of a theatre workshop in developing e ff ective communication in paediatric end of life care. Nurse Education in Practice, 36(February), 7-12. https://doi.org/10.1016/j.nepr.2019.02.014

Ok, E., Kutlu, F. Y., \& Ates, E. (2019). Issues in Mental Health Nursing The Effect of Standardized Patient Simulation Prior to Mental Health Rotation on Nursing Students ' Anxiety and Communication Skills The Effect of Standardized Patient Simulation Prior to Mental Health Rotation on Nursing Students ' Anxiety and Communication Skills. Issues in Mental Health Nursing, O(0), 1-5. https://doi.org/10.1080/01612840.2019.1642427

Öztürk, H. (2015). Communication proplems experienced by nursing students in clinics. 93, 2227-2232. https://doi.org/10.1016/j.sbspro.2013.10.194

Stevens, N., Mcniesh, S., \& Goyal, D. (2019). Students to Improve Communication Skills. 


\section{STRADA Jurnal Ilmiah Kesehatan}

DOI: $10.30994 /$ sjik.v9i2.420

ISSN: 2252-3847 (print); 2614-350X (online)

Vol.9 No.2 November 2020 Page.1238-1249

OO(0), 1-2. https://doi.org/10.1111/jan.12307

Sukamto, F. I., \& Putri, D. R. (2019). EFEKTIFITAS METODE SIMULASI : ROLE PLAY TERHADAP PENINGKATAN PENGETAHUAN MASYARAKAT TENTANG BASIC LIFE SUPPORT (BLS) DI KELURAHAN SETONO KABUPATEN PONOROGO. Dinamika Kesehatan Jurnal Kebidanan Dan Keperawatan, 10(1).

Wang, W., Liang, Z., Blazeck, A., \& Greene, B. (2015). Nurse Education Today Improving Chinese nursing students ' communication skills by utilizing videostimulated recall and role-play case scenarios to introduce them to the SBAR technique. YNEDT, 35(7), 881-887. https://doi.org/10.1016/j.nedt.2015.02.010

Webster, K. E. F., \& Carlson, E. (2019). Building therapeutic connections with the acutely ill through standardised patient simulation in nurse education an evaluation study. Nurse Education Today, 104261. https://doi.org/10.1016/j.nedt.2019.104261

White, K. A. (2015). Development and Validation of a Tool to Measure Self-Confi dence and Anxiety in. https://doi.org/10.3928/01484834-20131118-05

Yeh, V. J., Sherwood, G., Durham, C. F., Kardong-edgren, S., Schwartz, T. A., \& Beeber, L. S. (2019). Online Simulation-Based Mastery Learning with Deliberate Practice: Developing Interprofessional Communication Skill. Clinical Simulation in Nursing, 32, 27-38. https://doi.org/10.1016/j.ecns.2019.04.005

$\mathrm{Yu}, \mathrm{M}$. (2017). Effectiveness of a role-play simulation program involving the sbar technique: A quasi-experimental stud. https://doi.org/10.1016/j.nedt.2017.04.002 